\title{
RELATION OF CIRCULATING RED CELL VOLUME TO BODY DENSITY AND OBESITY ${ }^{1}$
}

\author{
By REX L. HUFF AND D. D. FELLER \\ (From the Radioisotope Unit and Medical Service, Seattle Veterans Administration Hospital, \\ and the Department of Medicine, University of Washington School of \\ Medicine, Seattle, Wash.)
}

(Submitted for publication June 27, 1955; accepted September 7, 1955)

The over-all metabolic activity of adipose tissue in man and other mammals has not been defined as carefully as that of other major organs and tissues. Despite recent reports $(1,2)$ showing that adipose tissue partakes in many biochemical reactions common to other tissues, widespread opinion holds that fat depots serve little purpose other than storage.

A primary index of metabolic activity in any organ is the blood flow through the organ. In this regard, some investigators favor the opinion that blood volume in the adult remains unaltered as body weight increases with fat deposition, and therefore blood volume and body weight correlate poorly in adults and should be well correlated with lean body weight $(3,4)$.

The study reported here was undertaken in order to obtain an estimate of the range of circulating red cell volume in men and women having differing degrees of obesity in an attempt to assess the relative importance of obesity tissue as an "organ" associated with a "fixed" quantity of blood.

\section{METHODS}

\section{Circulating red cell volume}

A modification of the technique of Sterling and Gray (5) was used for measuring circulating red cell volume. About 10 to 20 microcuries of chromium 51 in 0.01 to 0.2 ml. containing about 20 to 120 micrograms sodium chromate was injected into a sterile rubber-capped $15 \mathrm{ml}$. centrifuge tube. About 10 to 12 milliliters of the subject's heparinized blood was added to the solution and incubated for 45 minutes at room temperature. The incubated blood was spun at $1500 \mathrm{rpm}$ for 5 minutes in an International centrifuge (size 2 , model $R$ ). The supernatant was then withdrawn and the cell mass reconstituted with saline. The latter procedure was repeated twice. An aliquot of one milliliter, measured in a 1-milliliter calibrated syringe, was injected into a 100-milli-

1 This work was supported in part by a grant from the Life Insurance Medical Research Fund. liter volumetric flask for a standard, and the remainder was given to the recumbent subject by a single intravenous injection. The quantity given was estimated by reading from the calibration of the 10-milliliter syringe. Venous blood samples were drawn with a heparinized syringe at 5 and 10 minutes after injection, and two 4milliliter aliquots of each sample were pipetted into vials, spun at $1000 \mathrm{rpm}$ for 5 minutes, and analyzed in a conventional well-crystal detector. Efficiency of the wellcrystal detector was constant for any volume up to 2.5 milliliters. Hematocrits were measured by centrifuging blood at $3000 \mathrm{rpm}$ for one-half hour. Two-milliliter aliquots from the 100 -milliliter volumetric flask were counted in a similar manner for calculation of the amount of radioactivity injected.

Circulating red cell volume was calculated as follows:

$$
\begin{aligned}
& \frac{(\mathrm{Cts} . / \mathrm{min} . / \mathrm{ml} \text {. std. })(100)(\mathrm{ml} \text {. injected) }}{\text { Cts./min./ml. blood }} \\
& \begin{array}{l}
\text { Hct. } \\
\text { = Circulating red cell volume (CRCV) }
\end{array}
\end{aligned}
$$

No correction was made for retained plasma between the packed cells.

Blood volume was calculated by the following formula:

2. $\frac{(\text { Cts. } / \mathrm{min} . / \mathrm{ml} . \mathrm{std} .)(100)(\mathrm{ml} \text {. injected })}{\text { Cts. } / \mathrm{min} . / \mathrm{ml} \text {. blood }}$

and

$=$ Circulating blood volume

3. Plasma volume by the difference of " 2 " and " 1 ".

We believe, that with the exception of retained plasma in the packed cells, this method measures circulating red cell volume; plasma volume and blood volume are calculated values and not measured values. The former reservation is made because of the general knowledge of the possible difference in the total body hematocrit and the sampled hematocrit.

\section{Body density}

Weight of the subjects was determined with a standard physician's scale which had been calibrated with known volumes of water at a known temperature. Gross body volume was obtained from the volume of water displaced by the patient when he was immersed with the chest in full expiratory phase. Immersion was in an upright cylindrical galvanized iron tank. The tank was designed with metal rungs along the inside wall. The subject was instructed to forcibly exhale just prior to 
submersion. The rungs aided the subject to attain and maintain submersion in a half sitting posture.

The water of the tank was connected through a tube from the bottom to a burette on the side. The tank was calibrated by recording burette readings with the addition of 2-liter aliquots of water. A calibration curve was thus obtained from which the volume represented between any two points on the burette could be read. Water temperature was usually maintained in the range of $34^{\circ}$ to $37^{\circ} \mathrm{C}$. The volume of an inanimate object could be measured with this system to an accuracy of \pm 0.25 liters.

Residual lung volume was measured by the closed circuit method of Christie using the apparati and applying the formulae described by him (6). The subjects were seated in a fashion simulating their posture in the tank and instructed to forcibly exhale to the same expiratory point, before and after connection to the spirometer. Although this procedure did not measure "true residual air" and was subject to error on the part of subject participation, values obtained were considered well within the over-all accuracy required by the design of the experiment.

The mean values for residual lung volumes were found to be 2.54 liters for men and 2.03 liters for women with standard deviations of .08 liters and .05 liters, respectively.

Body density was then the quotient of the weight and the net body volume (immersion volume minus the residual lung volume). This measurement is density, or mass of body per unit volume, and can be converted to specific gravity by dividing by the density of water at

TABLE I .

Normal men

\begin{tabular}{|c|c|c|c|c|c|c|c|c|c|c|}
\hline Subject & $\begin{array}{c}\text { Age } \\
\text { (Yrs.) }\end{array}$ & $\underset{(M \text {. }}{\text { Ht. }}$ & $\underset{(\text { kg. })}{\text { Wt. }}$ & $\underset{(k g .)}{\text { Lean wt.* }}$ & $\underset{(\text { kg. })}{\text { Fat wt.* }}$ & R. $\underset{(L .)}{\text { C. vol. }}$ & $\underset{(L .)}{\text { Plasma vol. }}$ & $\underset{\%}{\text { Hct. }}$ & $\underset{(L .)}{\text { Blood vol. }}$ & $\begin{array}{c}\text { Body vol. } \\
(L .)\end{array}$ \\
\hline $\begin{array}{r}1 \\
2 \\
3 \\
4 \\
5 \\
6 \\
7 \\
8 \\
9 \\
10 \\
11 \\
12 \\
13 \\
14 \\
15 \\
16 \\
17 \\
18 \\
19 \\
20 \\
21 \\
22 \\
23 \\
24 \\
25 \\
26 \\
27 \\
28 \\
29 \\
30 \\
31 \\
32 \\
33 \\
34 \\
35 \\
36 \\
37 \\
38 \\
39 \\
40 \\
41 \\
42\end{array}$ & $\begin{array}{l}32 \\
21 \\
28 \\
38 \\
26 \\
48 \\
32 \\
27 \\
32 \\
31 \\
38 \\
48 \\
24 \\
37 \\
34 \\
54 \\
30 \\
45 \\
36 \\
24 \\
26 \\
30 \\
29 \\
60 \\
34 \\
29 \\
30 \\
31 \\
28 \\
28 \\
32 \\
27 \\
22 \\
20 \\
21 \\
29 \\
34 \\
30 \\
28 \\
32 \\
16 \\
26\end{array}$ & $\begin{array}{l}1.81 \\
1.73 \\
1.88 \\
1.70 \\
1.73 \\
1.70 \\
1.79 \\
1.78 \\
1.85 \\
1.82 \\
1.82 \\
1.84 \\
1.71 \\
1.74 \\
1.71 \\
1.67 \\
1.79 \\
1.80 \\
1.66 \\
1.88 \\
1.83 \\
1.69 \\
1.78 \\
1.70 \\
1.88 \\
1.72 \\
1.90 \\
1.78 \\
1.84 \\
1.79 \\
1.78 \\
1.68 \\
1.78 \\
1.84 \\
1.83 \\
1.77 \\
1.84 \\
1.70 \\
1.74 \\
1.84 \\
1.86 \\
1.93\end{array}$ & $\begin{array}{r}73.9 \\
67.6 \\
78.8 \\
97.8 \\
64.4 \\
67.5 \\
74.0 \\
94.5 \\
83.4 \\
71.0 \\
100.4 \\
97.5 \\
80.5 \\
100.9 \\
59.0 \\
109.5 \\
92.9 \\
112.5 \\
127.7 \\
69.8 \\
73.6 \\
59.3 \\
81.5 \\
92.5 \\
62.4 \\
69.0 \\
74.4 \\
82.2 \\
77.3 \\
110.3 \\
69.0 \\
61.4 \\
64.8 \\
75.3 \\
75.3 \\
71.6 \\
83.9 \\
69.9 \\
83.8 \\
81.0 \\
86.9 \\
84.6\end{array}$ & $\begin{array}{l}47.0 \\
43.9 \\
47.8 \\
48.7 \\
55.1 \\
50.6 \\
38.8 \\
57.8 \\
52.0 \\
54.0 \\
57.2 \\
60.8 \\
46.4 \\
42.3 \\
49.0 \\
67.9 \\
60.6 \\
78.1 \\
65.4 \\
57.9 \\
62.6 \\
56.3 \\
57.1 \\
51.8 \\
52.4 \\
50.6 \\
59.8 \\
53.2 \\
63.4 \\
54.7 \\
62.1 \\
58.3 \\
42.1 \\
67.8 \\
65.5 \\
61.6 \\
56.4 \\
50.5 \\
72.5 \\
66.0 \\
79.4 \\
74.7\end{array}$ & $\begin{array}{r}26.9 \\
23.7 \\
31.0 \\
49.1 \\
9.3 \\
16.9 \\
35.2 \\
36.7 \\
31.4 \\
17.0 \\
43.2 \\
36.7 \\
34.1 \\
58.6 \\
10.0 \\
41.6 \\
32.3 \\
34.4 \\
62.3 \\
11.9 \\
11.0 \\
3.0 \\
24.4 \\
40.7 \\
10.0 \\
18.4 \\
14.6 \\
29.0 \\
13.9 \\
55.6 \\
6.9 \\
3.1 \\
22.7 \\
7.5 \\
9.8 \\
10.0 \\
27.5 \\
19.4 \\
11.3 \\
15.0 \\
7.5 \\
9.9\end{array}$ & $\begin{array}{l}1.99 \\
2.06 \\
1.73 \\
2.66 \\
1.58 \\
2.34 \\
1.72 \\
2.60 \\
2.00 \\
2.17 \\
2.16 \\
3.06 \\
2.18 \\
2.54 \\
1.86 \\
2.50 \\
2.39 \\
2.72 \\
3.26 \\
2.53 \\
2.16 \\
1.90 \\
1.95 \\
2.96 \\
1.97 \\
1.78 \\
2.40 \\
2.12 \\
2.28 \\
2.80 \\
2.00 \\
2.44 \\
2.00 \\
2.37 \\
2.08 \\
2.33 \\
2.08 \\
2.20 \\
2.30 \\
1.62 \\
2.44 \\
2.51\end{array}$ & $\begin{array}{l}2.67 \\
2.02 \\
2.58 \\
2.99 \\
1.80 \\
2.52 \\
2.03 \\
2.99 \\
2.60 \\
2.81 \\
2.63 \\
2.56 \\
2.74 \\
3.07 \\
2.00 \\
2.53 \\
2.71 \\
3.07 \\
2.99 \\
3.11 \\
2.51 \\
2.47 \\
2.46 \\
3.19 \\
2.51 \\
2.24 \\
2.56 \\
2.72 \\
2.64 \\
3.05 \\
2.49 \\
2.53 \\
2.51 \\
3.12 \\
3.01 \\
2.77 \\
2.42 \\
2.37 \\
2.83 \\
2.55 \\
2.99 \\
3.49\end{array}$ & $\begin{array}{l}42.7 \\
50.5 \\
40.2 \\
47.2 \\
46.8 \\
48.2 \\
45.9 \\
46.5 \\
43.6 \\
41.5 \\
45.1 \\
54.6 \\
44.4 \\
45.0 \\
48.2 \\
49.6 \\
46.9 \\
47.0 \\
52.3 \\
44.8 \\
46.0 \\
43.4 \\
45.3 \\
48.9 \\
44.1 \\
44.3 \\
48.3 \\
43.7 \\
46.4 \\
47.8 \\
44.6 \\
49.2 \\
44.4 \\
43.9 \\
40.9 \\
45.7 \\
46.3 \\
48.0 \\
44.9 \\
39.0 \\
45.0 \\
43.0\end{array}$ & $\begin{array}{l}4.66 \\
4.08 \\
4.31 \\
5.64 \\
3.38 \\
4.86 \\
3.74 \\
5.59 \\
4.60 \\
4.98 \\
4.79 \\
5.62 \\
4.92 \\
5.61 \\
3.85 \\
5.03 \\
5.10 \\
5.79 \\
6.25 \\
5.64 \\
4.67 \\
4.37 \\
4.31 \\
6.05 \\
4.48 \\
4.02 \\
4.96 \\
4.84 \\
4.92 \\
5.85 \\
4.49 \\
4.97 \\
4.51 \\
5.39 \\
5.09 \\
5.10 \\
4.50 \\
4.57 \\
5.13 \\
4.17 \\
5.43 \\
6.00\end{array}$ & $\begin{array}{r}71.75 \\
65.46 \\
76.79 \\
97.12 \\
60.06 \\
64.11 \\
73.10 \\
92.06 \\
80.98 \\
67.35 \\
98.42 \\
94.71 \\
78.87 \\
101.56 \\
55.30 \\
106.55 \\
89.88 \\
107.99 \\
126.45 \\
65.41 \\
68.69 \\
54.37 \\
78.15 \\
90.71 \\
58.39 \\
65.80 \\
70.07 \\
79.59 \\
72.61 \\
110.18 \\
63.88 \\
56.90 \\
62.70 \\
69.65 \\
70.08 \\
66.72 \\
80.84 \\
66.59 \\
78.07 \\
76.13 \\
79.08 \\
78.63\end{array}$ \\
\hline $\begin{array}{l}\text { Mean } \\
\text { S.D. }\end{array}$ & $\begin{array}{r}32 \\
9\end{array}$ & $\begin{array}{l}1.78 \\
0.07\end{array}$ & $\begin{array}{l}81.3 \\
15.6\end{array}$ & $\begin{array}{r}63.88 \\
9.16\end{array}$ & $\begin{array}{l}17.40 \\
11.01\end{array}$ & $\begin{array}{l}2.26 \\
0.37\end{array}$ & $\begin{array}{l}2.66 \\
0.35\end{array}$ & $\begin{array}{r}45.8 \\
3.0\end{array}$ & $\begin{array}{l}4.91 \\
0.66\end{array}$ & $\begin{array}{l}77.90 \\
16.40\end{array}$ \\
\hline
\end{tabular}

* These values were calculated from the Rathbun-Pace fat prediction equation (7). 
TABLE II

Normal women

\begin{tabular}{|c|c|c|c|c|c|c|c|c|c|c|}
\hline Subject & $\begin{array}{c}\text { Age } \\
\left(\boldsymbol{Y}_{r s .}\right)\end{array}$ & $\begin{array}{l}\text { Ht. } \\
\text { (M.) }\end{array}$ & $\underset{(k g .)}{W t .}$ & ${ }_{(k g .)}^{\text {Lean wt.* }}$ & $\underset{(\text { kg. })}{\text { Fat wt.* }}$ & R. $\underset{(\text { L. })}{\text { C. }}$ vol. & $\underset{(L .)}{\text { Plasma vol. }}$ & Hct. & $\begin{array}{c}\text { Blood vol. } \\
(L .)\end{array}$ & $\begin{array}{c}\text { Body vol. } \\
(L .)\end{array}$ \\
\hline $\begin{array}{r}1 \\
2 \\
3 \\
4 \\
5 \\
6 \\
7 \\
8 \\
9 \\
10 \\
11 \\
12 \\
13 \\
14 \\
15 \\
16 \\
17 \\
18 \\
19 \\
20\end{array}$ & $\begin{array}{l}35 \\
30 \\
30 \\
29 \\
34 \\
25 \\
26 \\
30 \\
29 \\
28 \\
30 \\
57 \\
66 \\
37 \\
46 \\
25 \\
36 \\
29 \\
62 \\
31\end{array}$ & $\begin{array}{l}1.59 \\
1.63 \\
1.71 \\
1.62 \\
1.68 \\
1.76 \\
1.67 \\
1.59 \\
1.60 \\
1.67 \\
1.62 \\
1.59 \\
1.56 \\
1.68 \\
1.76 \\
1.62 \\
1.64 \\
1.72 \\
1.69 \\
1.59\end{array}$ & $\begin{array}{l}41.7 \\
62.3 \\
69.7 \\
61.4 \\
81.3 \\
59.8 \\
62.6 \\
48.7 \\
51.1 \\
54.8 \\
49.4 \\
55.6 \\
65.1 \\
72.7 \\
74.7 \\
57.1 \\
50.9 \\
64.6 \\
65.1 \\
48.9\end{array}$ & $\begin{array}{l}38.4 \\
43.0 \\
38.3 \\
36.2 \\
39.8 \\
53.1 \\
46.9 \\
28.7 \\
42.4 \\
34.2 \\
41.0 \\
30.1 \\
31.2 \\
54.2 \\
50.8 \\
46.4 \\
43.1 \\
41.7 \\
31.3 \\
31.9\end{array}$ & $\begin{array}{r}3.3 \\
19.3 \\
31.4 \\
25.2 \\
41.5 \\
6.7 \\
15.7 \\
20.0 \\
8.7 \\
20.6 \\
8.4 \\
25.5 \\
33.9 \\
18.5 \\
23.9 \\
10.7 \\
7.8 \\
22.9 \\
33.8 \\
17.0\end{array}$ & $\begin{array}{l}1.23 \\
1.66 \\
1.67 \\
1.60 \\
1.70 \\
1.47 \\
1.21 \\
1.27 \\
1.35 \\
1.39 \\
1.36 \\
1.27 \\
1.37 \\
1.72 \\
1.52 \\
1.47 \\
1.20 \\
1.37 \\
1.57 \\
1.27\end{array}$ & $\begin{array}{l}1.53 \\
2.07 \\
2.15 \\
1.98 \\
2.68 \\
2.13 \\
2.12 \\
1.75 \\
1.79 \\
2.03 \\
1.76 \\
2.07 \\
1.73 \\
2.63 \\
2.45 \\
2.25 \\
1.96 \\
2.09 \\
2.06 \\
1.99\end{array}$ & $\begin{array}{l}44.4 \\
44.7 \\
43.9 \\
44.5 \\
38.7 \\
40.8 \\
36.3 \\
42.0 \\
42.9 \\
40.6 \\
43.4 \\
38.4 \\
44.1 \\
39.4 \\
38.3 \\
39.5 \\
38.0 \\
39.7 \\
43.0 \\
38.9\end{array}$ & $\begin{array}{l}2.76 \\
3.73 \\
3.82 \\
3.58 \\
4.37 \\
3.60 \\
3.33 \\
3.02 \\
3.14 \\
3.41 \\
3.12 \\
3.34 \\
3.10 \\
4.35 \\
3.97 \\
3.72 \\
3.16 \\
3.46 \\
3.63 \\
3.25\end{array}$ & $\begin{array}{l}38.47 \\
59.87 \\
68.57 \\
60.04 \\
80.85 \\
55.44 \\
59.48 \\
47.50 \\
47.86 \\
53.28 \\
46.26 \\
54.79 \\
64.79 \\
69.23 \\
71.90 \\
54.66 \\
47.57 \\
63.30 \\
64.78 \\
47.29\end{array}$ \\
\hline $\begin{array}{l}\text { Mean } \\
\text { S.D. }\end{array}$ & $\begin{array}{l}36 \\
11\end{array}$ & $\begin{array}{l}1.65 \\
0.06\end{array}$ & $\begin{array}{r}59.9 \\
9.8\end{array}$ & $\begin{array}{r}45.33 \\
6.69\end{array}$ & $\begin{array}{r}14.54 \\
7.08\end{array}$ & $\begin{array}{l}1.43 \\
0.17\end{array}$ & $\begin{array}{l}2.06 \\
0.28\end{array}$ & $\begin{array}{r}41.1 \\
2.6\end{array}$ & $\begin{array}{l}3.49 \\
0.41\end{array}$ & $\begin{array}{l}57.80 \\
10.21\end{array}$ \\
\hline
\end{tabular}

* These values were obtained from the Rathbun-Pace fat prediction equation (7).

that temperature. Specific gravity assignment of the living human body is limited in general to a comparison of water at $37^{\circ} \mathrm{C}$.

The percentages of lean and fat weights of the subjects were determined independently from two fat prediction equations; namely,

1. Rathbun-Pace (7):

and

$$
\% \mathrm{~F}=100\left[\frac{5.548}{\text { sp.gr. }}-5.044\right]
$$

2. Keys-Brožek (8):

$$
F=\left[\frac{4.201}{D}-3.813\right]
$$

where sp. gr. = specific gravity

$$
\mathrm{D}=\text { density }
$$

Inherent in the method for measuring total body volume are those errors involved in measurements of gross body volume and residual lung volume as well as unmeasured volume of gas in the gastrointestinal tract. The most unfavorable estimate of error is obtained by adding the maximum estimated range of these three errors. This sum causes an approximate error of about 1 per cent in body density.

Comparison of the correlation coefficients obtained by the use of the data obtained from the two equations is discussed below.

\section{Subjects}

Most of the subjects were normal volunteers. Several of the most obese individuals were selected from the hospital files because their chief admission diagnosis was obesity, and because other findings were not considered significant. Most of the procedures for body volume and lung volume determinations were carried out between 11:00 a.m. and noon before lunch or after 4:00 p.m.

\section{RESULTS AND DISCUSSION}

Tables I and II give the data for men and women, respectively. Included are the age, height, weight, lean weight, fat weight, circulating red cell volume, calculated plasma volume, calculated blood volume, hematocrit, and body volume. The values for lean and fat weight were obtained using the Rathbun-Pace equation (7). Table III gives the means and standard deviations for the following measures of men and women: Circulating red cell

TABLE III

Blood volumes in normal male and female subjects (Mean \pm S.D.)

\begin{tabular}{ccc}
\hline \hline Measurement & Men (42)* & Women (20)* \\
\hline $\begin{array}{c}\text { Circulating red cell } \\
\text { vol. (Liters) }\end{array}$ & $2.26 \pm 0.37$ & $1.43 \pm 0.17$ \\
$\begin{array}{c}\text { Calculated blood } \\
\text { volume (Liters) }\end{array}$ & $4.91 \pm 0.66$ & $3.49 \pm 0.41$ \\
$\begin{array}{c}\text { Calculated plasma } \\
\text { volume (Liters) }\end{array}$ & $2.66 \pm 0.35$ & $2.06 \pm 0.28$ \\
$\begin{array}{c}\text { Circulating red cell } \\
\text { vol. (ml./kg.) }\end{array}$ & $28.27 \pm 4.11$ & $24.24 \pm 2.59$ \\
$\begin{array}{c}\text { Calculated plasma } \\
\text { volume (ml./kg.) }\end{array}$ & $33.45 \pm 5.18$ & $34.77 \pm 3.24$ \\
$\begin{array}{c}\text { Calculated blood } \\
\text { volume (ml./kg.) }\end{array}$ & $61.54 \pm 8.59$ & $58.95 \pm 4.94$ \\
\hline
\end{tabular}

* Number of subjects. 


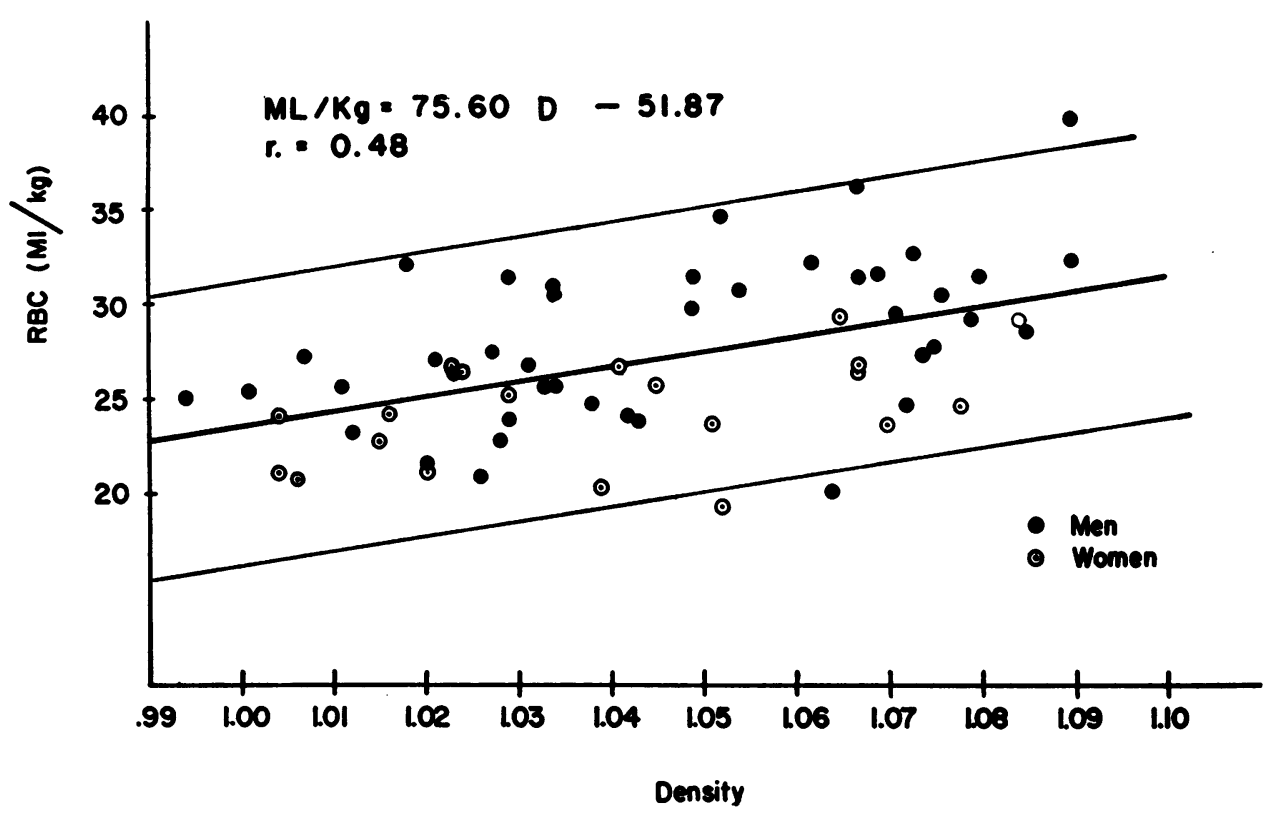

Fig. 1. Circulating Red Cell Volume Plotted Against Body Density of Forty-Two Men AND TWENTY WoMEN

Shown are the regression equation and correlation coefficient, "r." See text for regression equation and correlation coefficients for men and women separately.

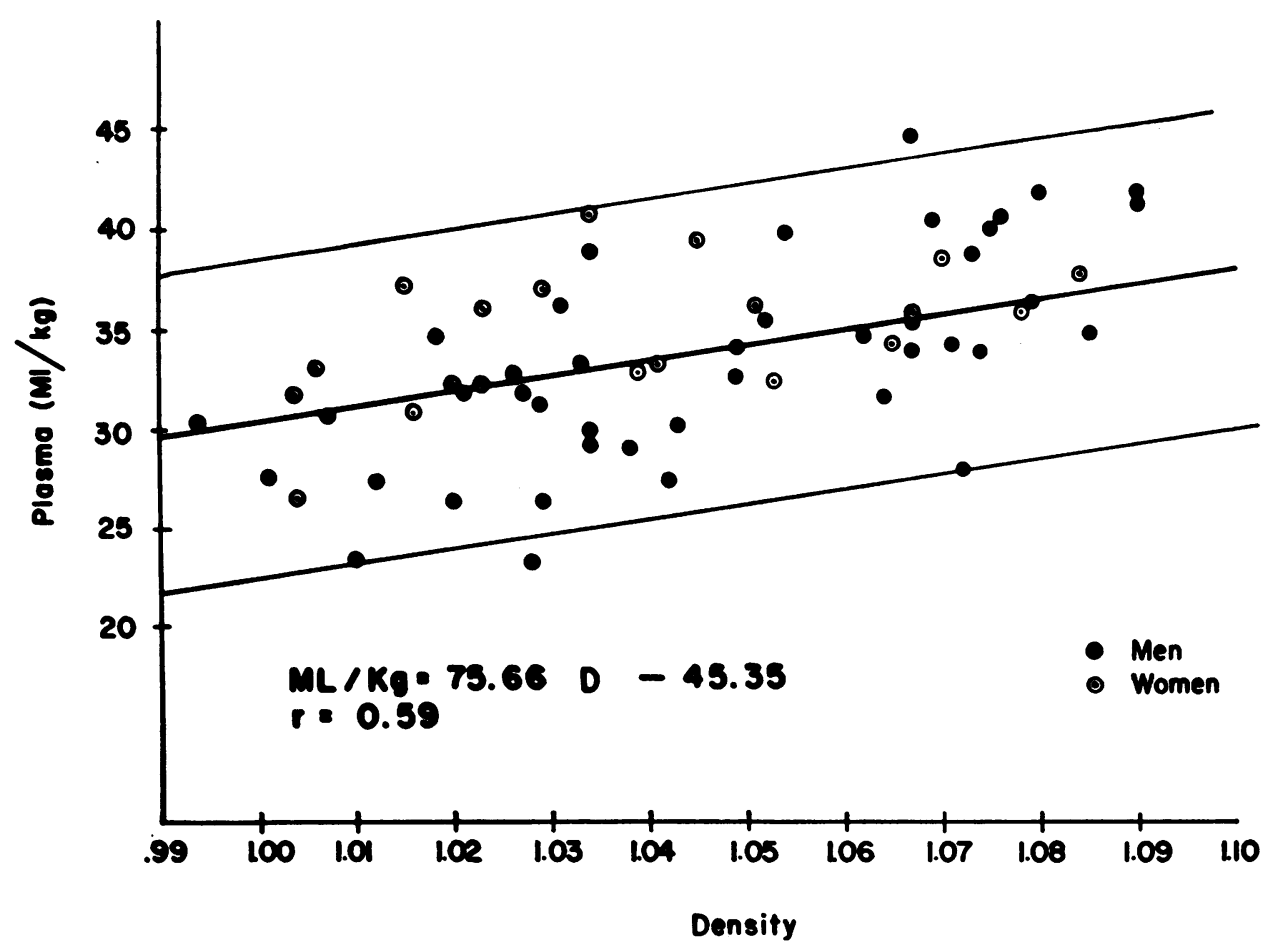

Fig. 2. Calculated Plasma Volume Plotred Against Body Density of Forty-Two Men ANd TWenty WoMen

Shown are the regression equation and correlation coefficient, "r." 


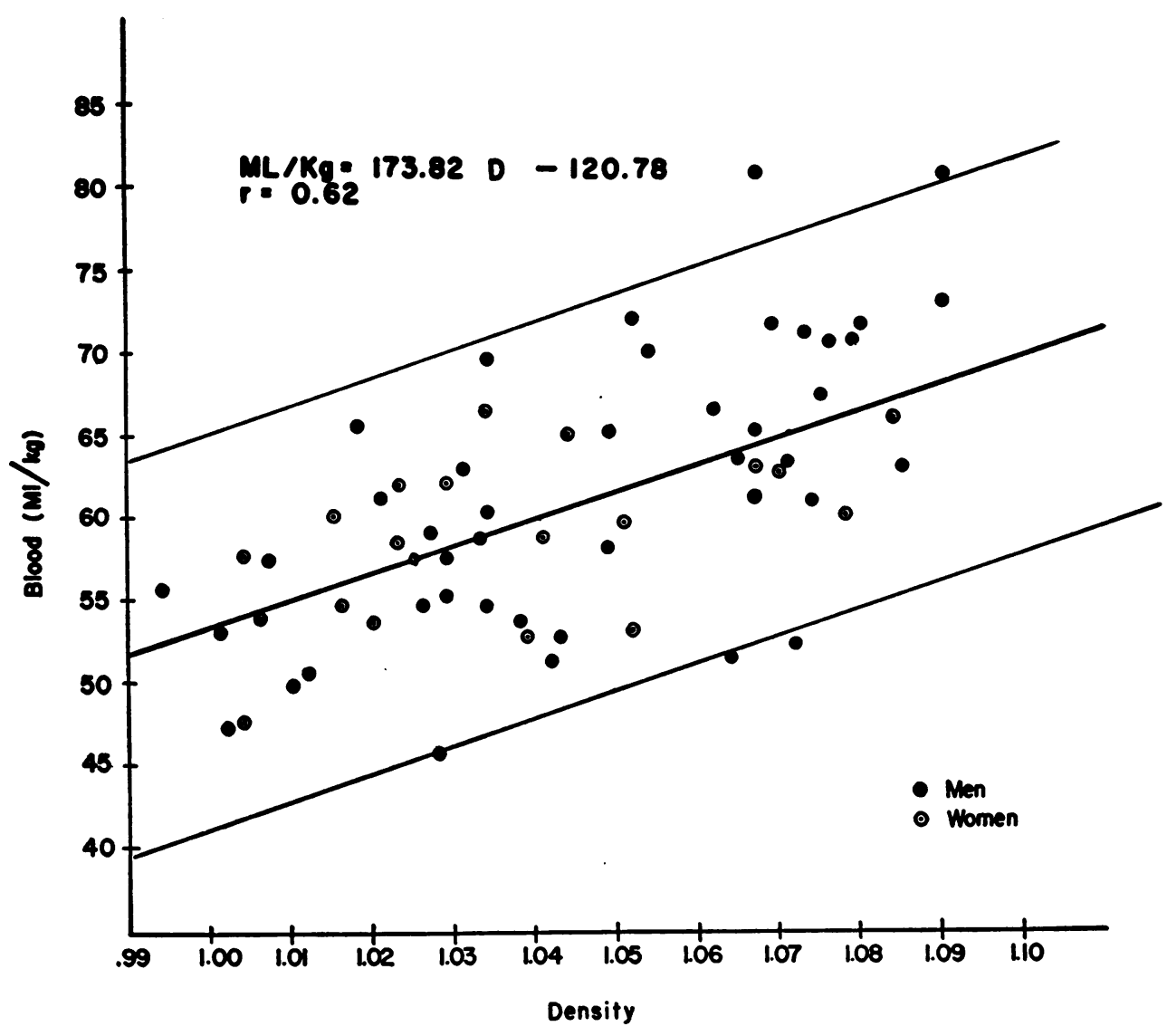

Fig. 3. Calculated Blood Volume Plotted Against Body Density of Forty-Two Men AND TWENTY WOMEN

Shown are the regression equation and correlation coefficient, "r."

volume, calculated blood volume and calculated plasma volume (liters), as well as the same measures per unit body weight. These values correspond closely to those reported by Berlin, Hyde, Parsons, and Lawrence (9) and Berlin, Hyde, Parsons, Lawrence, and Port (10).

Of particular interest in these data is the extent of the dispersion of the samples about the mean, due, undoubtedly, to the particular population selected for range of obesity. For this group, it appears that diagnosis of an increase in circulating red cell volume requires a value greater than $38 \mathrm{ml}$. per $\mathrm{kg}$. body weight for men and 29 $\mathrm{ml}$. per $\mathrm{kg}$. body weight for women. Ninety-five per cent of the population lies between 20 and 38 $\mathrm{ml}$. per kg. for men and 19 and $29 \mathrm{ml}$. per kg. for women. This range is about 29 per cent and 22 per cent of the mean for men and women, respectively.
In Figures 1, 2, and 3 are plotted the various volumes against body density. Also shown is the regression equation for each of these sets of data. The correlation coefficient for red cell volume and body density shown in Figure 1 is 0.48 and is highly significant. However, the distribution of the male and female population above and below the line is apparently not random. For any density there are a greater percentage of the data of women below the regression line for red cells. In fact there are only 3 of 20 of the data of females above the line. When the population is separated into men and women, the following regression equations were found:

$$
\begin{aligned}
& \text { Men (42 subjects) } \\
& \text { CRCV (ml./kg.) = 80.03 D }-55.51 \\
& \text { Women ( } 20 \text { subjects) } \\
& \text { CRCV (ml./kg.) }=47.25 \mathrm{D}-24.83
\end{aligned}
$$


where $\mathrm{D}=$ body density. For all values of density, the volume of red cells calculated for women from the regression equation were lower than for men.

Figure 2, which illustrates the calculated plasma volume plotted against the body density, suggests an opposite relationship wherein, for any degree of obesity, a female has more plasma than a male.

These data show that the volume of cells and plasma per unit body weight are less for increasing degrees of obesity, and correspond to the suggestions of Gibson and Evans (11), Gregersen and Nickerson (12), Perera (13), and Hardy and Drabkin (14).

It is of interest to note and discuss the values of extrapolation of the regression lines of Figures 1 and 2 to a density of 0.948 - a value considered by Keys and Brožek (8) as representative of human obesity tissue. The value thus obtained for red cell volume of this type of tissue is $20.0 \pm$ $3.7 \mathrm{ml}$. per kg.

This experimental extrapolated value for red cell volume of obesity tissue may be compared to a value calculated from data such as extracellular fluid content of obesity tissue and the ratio of extracellular fluid to red cell volume in the body. The ratio of extracellular fluid volume to circu- lating red cell volume calculated from data obtained on 12 healthy adults reported by Hay, Hay, and Jenkins (15) is approximately 6.8. Observations of Keys and Brožek (8) indicate that a mean value of 14.2 per cent of obesity tissue, added when a healthy man gains weight, is accounted for as extracellular fluid. Using, then, the ratio of 6.8 , one would expect the circulating red cell volume of obesity tissue to be $20.8 \mathrm{ml}$. per $\mathrm{kg}$. which may be compared to our extrapolated value of $20.0 \pm 3.7 \mathrm{ml}$. per $\mathrm{kg}$.

Similarly, extrapolation of the line in Figure 2 to a density of 0.948 gives a value for plasma volume of $26.2 \pm 4 \mathrm{ml}$. per $\mathrm{kg}$. of obesity tissue. The ratio of extracellular fluid volume to plasma volume is approximately 5.2 (15) which would give an expected plasma volume of $27.3 \mathrm{ml}$. per $\mathrm{kg}$.

\section{Data analysis by derivation of multivariant regres- sion equations}

It was thought that estimates of red cell volume might be improved by including variables other than the customary weight or surface area in a multiple regression equation. Also it seemed possible that the various available parameters might be evaluated with relation to their appropriate weight or significance. Inspection of the data

TABLE IV

Di- and trivariant correlation coefficients for volumes and lean weight, or fat weight, and lean and fat weight calculated independently from two fat prediction equations

\begin{tabular}{|c|c|c|c|c|c|c|c|}
\hline \multirow[b]{2}{*}{$\begin{array}{l}\text { Blood compartment } \\
\text { (listers) }\end{array}$} & \multirow[b]{2}{*}{ Population } & \multicolumn{2}{|c|}{$\underset{(k g .)}{\text { Lean body mass }}$} & \multicolumn{2}{|c|}{$\underset{(\mathrm{kg} .)}{\text { Fat weight }}$} & \multicolumn{2}{|c|}{$\begin{array}{l}\text { Lean body mass } \\
\text { and fat weight }\end{array}$} \\
\hline & & $\begin{array}{c}\text { Rathbun- } \\
\text { Pace }\end{array}$ & $\begin{array}{l}\text { Keys- } \\
\text { Brožel }\end{array}$ & $\begin{array}{c}\text { Rathbun- } \\
\text { Pace }\end{array}$ & $\begin{array}{c}\text { Keys- } \\
\text { Brozek }\end{array}$ & $\begin{array}{c}\text { Rathbun- } \\
\text { Pace }\end{array}$ & $\begin{array}{c}\text { Keys- } \\
\text { Brožek } \\
\end{array}$ \\
\hline $\begin{array}{l}\text { Circulating red cell } \\
\text { volume }\end{array}$ & $\begin{array}{c}\text { Total } \\
(62)^{*}\end{array}$ & $.670 \dagger$ & .806 & .429 & .422 & & \\
\hline $\begin{array}{l}\text { Calculated blood } \\
\text { volume }\end{array}$ & $\begin{array}{c}\text { Total } \\
(62)\end{array}$ & .719 & .840 & .392 & .388 & & \\
\hline $\begin{array}{l}\text { Calculated plasma } \\
\text { volume }\end{array}$ & $\begin{array}{r}\text { Total } \\
(62)\end{array}$ & .701 & .791 & .307 & .307 & & \\
\hline $\begin{array}{l}\text { Circulating red cell } \\
\text { volume }\end{array}$ & $\begin{array}{l}\text { Women } \\
(20)\end{array}$ & $.296 t$ & .559 & .518 & .522 & .759 & .759 \\
\hline $\begin{array}{l}\text { Calculated blood } \\
\text { volume }\end{array}$ & $\begin{array}{l}\text { Women } \\
\text { (20) }\end{array}$ & .476 & .733 & .497 & .518 & .890 & .891 \\
\hline $\begin{array}{l}\text { Calculated plasma } \\
\text { volume }\end{array}$ & $\begin{array}{l}\text { Women } \\
(20)\end{array}$ & .516 & .738 & $.421 \ddagger$ & .448 & .862 & .856 \\
\hline $\begin{array}{l}\text { Circulating red cell } \\
\text { volume }\end{array}$ & Men & .342 & .585 & .500 & .504 & .708 & .707 \\
\hline $\begin{array}{l}\text { Calculated blood } \\
\text { volume }\end{array}$ & $\begin{array}{l}\text { Men } \\
(42)\end{array}$ & .435 & .640 & .417 & .423 & .711 & .708 \\
\hline $\begin{array}{l}\text { Calculated plasma } \\
\text { volume }\end{array}$ & $\begin{array}{l}\text { Men } \\
(42)\end{array}$ & .457 & .579 & $.249 \ddagger$ & .257 & .602 & .597 \\
\hline
\end{tabular}

* Figures in parentheses represent sample number.

+ See Table $V$ for values of $r$ at different levels of significance.

\$ These values for $r$ are not significantly different from zero at 5 per cent level of probability. 
shown in Figure 1 suggested that circulating red cell volume of women should be considered separately from that of men. Therefore, the regression models were calculated for men and women separately. Two models of linear regression were investigated for each sex, since there were insufficient data to suggest other than linear relationships. These models were tested for the calculated blood volumes as well as the measured red cell volume.

Both the Rathbun-Pace (7) and Keys-Brožek (8) body fat prediction equations were used for the multivariant analyses which included lean weight and fat weight. The multiple correlation coefficients for these parameters are given in Table IV. Also shown in Table IV are bivariate correlation coefficients for fat or lean weight with blood, plasma or cell volume.

Using the Rathbun-Pace equation more comlex models than just lean weight and fat weight were tested for correlation. The first of these for 42 men included as variables body volume, height, weight, and age. The multiple correlation coefficient for this model was 0.71 and was highly significant with probability $<<0.01$ of being obtained by chance. However, tests of significance of the individual regression coefficients showed a definitely significant relationship with weight $(\mathrm{P}<.05)$, a possibly significant relationship with body volume $(P>.10)$ and no significant linear relationship with height and age.

The model was then revised to include only weight and body volume and for the 42 men was as follows:

Blood Volume (liters) $=0.123$ weight (kg.) -0.091 body volume (liters) +1.987 with $\mathrm{R}=0.71, \mathrm{P}<<.01, \mathrm{~s}=0.48$

Test of individual regression coefficients showed the linear relationship of blood volume to weight even more significant $(P<.02)$, while body volume was significant only at the 7 per cent level $(\mathrm{P}<0.07)$.

The corresponding equation from data obtained on 42 men for circulating red cell volume was as follows :

$$
\begin{gathered}
\text { CRCV (liters) }=0.044 \text { weight (kg.) } \\
-0.026 \text { body volume (liters) }+0.72 \\
\text { with } \mathrm{R}=0.71, \mathrm{P}<.001, \mathrm{~s}=0.27
\end{gathered}
$$

The data on 20 women were subjected to the same analyses using the same original model with body volume, height, weight, and age as variables. In contrast to the results obtained from the men's data, the two variables which proved to be significant when tested were age and weight, and the following equation was obtained :

$$
\begin{gathered}
\text { Blood Volume (liters) }=0.039 \text { weight }(\mathrm{kg} .) \\
-0.0018 \text { age (yrs.) }+1.248 \\
\text { with } \mathrm{R}=0.90, \mathrm{P}<.01, \mathrm{~s}=0.19
\end{gathered}
$$

The data from women gave an equation for circulating red cell volume as follows:

$$
\begin{gathered}
\text { CRCV (liters) }=0.0136 \text { weight (kg.) } \\
\qquad-0.002 \text { age (yrs.) }+0.707 \\
\text { with } \mathrm{R}=0.78, \mathrm{P}<.001, \mathrm{~s}=0.12
\end{gathered}
$$

A second model included as variables, lean weight, fat weight and surface area. Test of regression coefficients for surface area of the multiple equation showed no significant linear relationship to blood volume and circulating red cell volume for data of both men and women and was consequently deleted from the model. The four resulting equations were as follows:

\section{Men}

1) Blood Volume (liters) $=.042$ lean wt. (kg.) +0.025 fat wt. (kg.) +1.92

2) $\mathrm{CRCV}$ (liters) $=0.021$ lean wt. (kg.) + 0.016 fat wt. (kg.) +0.70

\section{Women}

1) Blood Volume (liters) $=0.045$ lean wt. (kg.) +0.034 fat wt. (kg.) +1.02

2) $\mathrm{CRCV}$ (liters) $=0.014$ lean wt. (kg.) + 0.013 fat wt. (kg.) +0.63

Tests of the regression coefficients showed highly significant linear relationship between these volumes and lean weight and fat weight, having $P$ values $<<.001$ in every case except one : circulating red cell volume (liters) and lean weight (kg.) in women had $\mathrm{P}>.01$.

Thus, these considerations suggest that there is a high degree of correlation between lean weight and red cell volume as well as plasma volume and blood volume. Moreover, it is equally strongly suggested that there is a high degree of correlation 
of these values with fat weight. It is interesting that the $\mathrm{P}$ value for the significance of the coefficient for fat weight in women $(<.001)$ was better, than that for lean, $<.01$. The tendency in the literature and in discussions has been to emphasize the quantity of blood allocated to lean tissue. It is true that in men the quantity of blood apparently associated with lean tissue is about twice that of fat; but in women this difference of fat and lean is much less.

The analyses do indicate very strongly that the correlation coefficient obtained by trivariant analysis when lean and fat weight are considered together as variables have higher values than when only lean weight is considered. Table IV shows a higher correlation coefficient for every

TABLE V

Comparison of correlation coefficients for blood volumes and surface area, total body weight, and log of body weight

\begin{tabular}{|c|c|c|c|c|c|}
\hline$\underset{\substack{\text { Blood } \\
\text { compartment }}}{\text { (liters) }}$ & Population & $\begin{array}{l}\text { Sample } \\
\text { number }\end{array}$ & $\underset{\substack{\text { Surface } \\
M^{2}}}{\substack{\text { and } \\
\text { nat }}}$ & $\begin{array}{c}\text { Total } \\
\text { body } \\
\text { weight } \\
\text { kg. }\end{array}$ & $\begin{array}{l}\text { Log of } \\
\text { body } \\
\text { weight } \\
\text { log } \mathrm{kg} .\end{array}$ \\
\hline $\begin{array}{l}\text { Circulating } \\
\text { red cell } \\
\text { volume }\end{array}$ & Total & 62 & $.876^{*}$ & .637 & .861 \\
\hline $\begin{array}{l}\text { Calculated } \\
\text { blood } \\
\text { volume }\end{array}$ & & & .867 & .891 & .890 \\
\hline $\begin{array}{c}\text { Calculated } \\
\text { plasma } \\
\text { volume }\end{array}$ & & & .824 & .734 & \\
\hline $\begin{array}{l}\text { Circulating } \\
\text { red cell } \\
\text { volume }\end{array}$ & Women & 20 & .753 & .763 & \\
\hline $\begin{array}{l}\text { Calculated } \\
\text { blood } \\
\text { volume }\end{array}$ & & & .871 & .873 & \\
\hline $\begin{array}{c}\text { Calculated } \\
\text { plasma } \\
\text { volume }\end{array}$ & & & .832 & .825 & \\
\hline $\begin{array}{l}\text { Circulating } \\
\text { red cell } \\
\text { volume }\end{array}$ & Men & 42 & .604 & .697 & \\
\hline $\begin{array}{l}\text { Calculated } \\
\text { blood } \\
\text { volume }\end{array}$ & & & .761 & .673 & .690 \\
\hline $\begin{array}{l}\text { Calculated } \\
\text { plasma } \\
\text { volume }\end{array}$ & & & .578 & .520 & \\
\hline
\end{tabular}

* For 62 subjects $r$ is significantly different from zero at the 5 per cent level of probability if $r=0.25$ and at the 1 per cent level if $r=0.32$. For 42 subjects similar values of $r$ are 0.30 and 0.39 , respectively. For 20 subjects similar values of $r$ are 0.42 and 0.54 , respectively. All $r$ 's in the table are significantly different from zero at 1 per cent level of probability. case when fat is included as a variable. In every case, there was also a slight decrease in dispersion. Thus, fat weight as well as lean weight must be considered when predicting blood volumes since lean weight alone gives a poorer correlation.

However, the multiple correlation coefficients of the trivariate analyses of fat weight, and lean weight with each of the volumes is no better than the bivariate correlation coefficients of total weight, or surface area, or logarithm of the body weight with each of the volumes. These last values are shown in Table $\mathrm{V}$. This raises the possibility that these parameters are basically related to blood volume but in themselves have little to do with the normal variations among individuals. An important question in this relation is, "What is the validity and reliability with which red cell volume may be measured with $\mathrm{Cr}^{51}$ ?" Evaluation of the error of this method is as difficult as it is important. It would be relatively simple to evaluate the error of the method for an in vitro system; however, the error associated with mixing is not apparently soluble at this time. Blood samples for measurement of the chromium-51 concentration were drawn at five and ten minutes. Inspection and comparison of the counting rates of the two samples did not suggest any significant systematic difference. Usually the difference in the values was less than the error of the analysis. The count rate of the second sample from markedly obese individuals was not less than that of their first sample. Therefore differences in mixing in obese individuals are likely to be evident in a comparison of samples drawn before five minutes. From these considerations, it is unlikely that the circulating red cell volume of obese individuals was incorrectly estimated because of prolonged mixing. It is our opinion that the apparent variation of 25 per cent between individuals is not the result of error of the method, but involves other parameters. Berlin, Hyde, Parsons, and Lawrence (9) found that with repeat determinations in a series of $24 \mathrm{P}^{32}$ tagged cell volumes, the maximum variation was 7.4 per cent and the average variation was 5.7 per cent.

For any density, the amount of circulating red cell mass per kilogram of tissue is less in women than in men. Therefore, the difference in circulating red cell mass in men and women is on a ba- 
sis other than obesity alone. The role of gonads in erythropoiesis has been reviewed by Van Dyke, Contopoulos, Williams, Simpson, Lawrence, and Evans (16), and additional data were presented showing that testosterone causes increased cell production and a greater circulating red cell volume while estrogen works an opposite effect (16). Hollingsworth and Hollingsworth (17) recently have collected data on $\mathrm{Cr}^{51}$ tagged red cell survival in women which suggest that cell longevity is less in women than in men.

The value obtained by extrapolation for the amount of blood in obesity tissue if applied to the lean individual who becomes very obese gives impressive increases in blood volume. For example, if a lean 60 kilogram man gains 40 kilograms of obesity tissue, it is implied that his former blood volume of about 4000 milliliters would be expected to increase to about 5200 milliliters. Thus, 1200 milliliters of blood would be associated with his obesity tissue.

The studies of Jones (18) indicate that fat tissue is relatively poorly perfused with blood. Taylor, Brožek, and Keys (19) have shown that the cardiac output does not increase with increases of obesity tissue. Contrariwise they showed a trivariate regression equation relating cardiac output to lean body mass and fat, and found that the coefficient for fat is negative. The same authors showed that the arterial-mixed venous oxygen difference was positively correlated with obesity.

The data here indicate that the amount of blood per unit obesity tissue is relatively large. Along with the findings of others regarding perfusion rates and cardiac output, these data emphasize the possible magnitude of relatively slow moving pools of blood in the obese individual and are pertinent to speculation concerning the increased incidence of death due to thromboembolism in individuals having these characteristics.

\section{SUMMARY}

Circulating red cell volume and body density were measured in a group of men and women. Multiple regression equations were derived showing that circulating red cell volume is significantly correlated with fat as well as lean tissue. The amount of blood associated with obesity tissue is apparently about two-thirds that of lean tissue. Since blood perfusion of obesity tissue is relatively low, this implies that obesity results in the presence of relatively large quantities of blood having low turnover rates. There was little increase in ability to estimate red cell volume on the basis of such equations when applied to an individual of this sample over the estimate based on weight alone. Women were found to have a circulating red cell volume per unit weight less than that of men for any degree of obesity.

\section{REFERENCES}

1. Feller, D. D., Metabolism of adipose tissue. I. Incorporation of acetate carbon into lipides by slices of adipose tissue. J. Biol. Chem., 1954, 206, 171.

2. Hausberger, F. X., Milstein, S. W., and Rutman, R. $\mathrm{J}$, The influence of insulin on glucose utilization in adipose and hepatic tissues in vitro. J. Biol. Chem., 1954, 208, 431.

3. Sjostrand, T., Regulatory mechanisms relating to blood volume. Minnesota Med., 1954, 37, 10.

4. Mayer, J., and Hagman, N. C., Total body water and blood volume in hereditary obese-hyperglycemic syndrome of mice. Proc. Soc. Exper. Biol. \& Med., 1953, 82, 647.

5. Sterling, K., and Gray, S. J., Determination of the circulating red cell volume in man by radioactive chromium. J. Clin. Invest., 1950, 29, 1614.

6. Christie, R. V., The lung volume and its subdivisions. I. Methods of measurement. J. Clin. Invest., 1932, 11, 1099.

7. Rathbun, E. N., and Pace, N., Studies on body composition: I. The determination of total body fat by means of the body specific gravity. J. Biol. Chem., $1945,158,667$.

8. Keys, A., and Brožek, J., Body fat in adult man. Physiol. Rev., 1953, 33, 245.

9. Berlin, N. I., Hyde, G. M., Parsons, R. J., and Lawrence, $\mathrm{J}$. H., The blood volume in various medical and surgical conditions. New England J. Med., 1952, 247, 675.

10. Berlin, N. I., Hyde, G. M., Parsons, R. J., Lawrence, J. H., and Port, S., Blood volume of the normal female as determined with $P^{2 s}$ labeled red blood cells. Proc. Soc. Exper. Biol. \& Med., 1951, 76, 831.

11. Gibson, J. G., 2nd, and Evans, W. A., Jr., Clinical studies of the blood volume. II. The relation of plasma and total blood volume to venous pressure, blood velocity rate, physical measurements, age and sex in ninety normal humans. J. Clin. Invest., 1937, 16, 317.

12. Gregersen, M. I., and Nickerson, J. L., Relation of blood volume and cardiac output to body type. $\mathrm{J}$. Applied Physiol., 1950, 3, 329. 
13. Perera, G. A., The effect of significant weight change on the predicted plasma volume. J. Clin. Invest., 1946, 25, 401.

14. Hardy, J. D., and Drabkin, D. L., The $D_{2} O$ dilution space as a measure of total body water and the relation of body water to body size. Am. J. Med. Sc., 1950, 219, 109.

15. Hay, E. B., Hay, C. R., and Jenkins, D. E., Blood volume and extracellular fluid in tuberculosis. $\mathrm{J}$. Thoracic Surg., 1951, 21, 42.

16. Van Dyke, D. C., Contopoulos, A. N., Williams, B. S., Simpson, M. E., Lawrence, J. H., and Evans,
H. M., Hormonal factors influencing erythropoiesis. Acta Haematol., 1954, 11, 203.

17. Hollingsworth, J. W., and Hollingsworth, D. R., Study of total red cell volume and erythrocyte survival using radioactive chromium in patients with advanced pulmonary tuberculosis. Ann. Int. Med., 1955, 42, 810.

18. Jones, H. B., Respiratory system: nitrogen elimination, in Medical Physics, Otto Glasser, Ed., Chicago, Yearbook Publishers, 1950, Vol. 2, p. 855.

19. Taylor, H. L., Brožek, J., and Keys, A., Basal cardiac function and body composition with special reference to obesity. J. Clin. Invest., 1952, 31, 976.

\section{SPECIAL NOTICE TO SUBSCRIBERS}

Post Offices will no longer forward the Journal when you move.

Please notify The Journal of Clinical Investigation, Business Office, 622 West 168 th Street, New York 32, N. Y. at once when you have a change of address, and do not omit the zone number if there is one. 